\title{
IMPLEMENTASI PEMBELAJARAN IPS GEOGRAFI BERBASIS KONTEKSTUAL DI MADRASAH
}

\author{
Rofiq Faudy Akbar \\ Institut Agama Islam Negeri Kudus \\ rofiq@stainkudus.ac.id
}

\begin{tabular}{|c|c|}
\hline Informasi artikel & ABSTRACT \\
\hline $\begin{array}{l}\text { Sejarah artikel: } \\
\text { Diterima } \\
\text { Revisi } \\
\text { Dipublikasikan } \quad \sqrt{ } \\
\text { Keyword: } \\
\text { IPS Geography, } \\
\text { Contextual, } \\
\text { Madrasah }\end{array}$ & $\begin{array}{l}\text { This study aims to determine; (1) Can the implementation of contextual-based } \\
\text { learning methods in class X social science subjects improve student } \\
\text { motivation? (2) Does the implementation of contextual-based learning } \\
\text { methods in class X social science geography subjects improve student } \\
\text { achievement? (3) What is the response of class X students regarding the } \\
\text { application of contextual based learning methods to geography social studies } \\
\text { subjects? The method used in this study is quantitative with an analytical } \\
\text { descriptive approach. The results of this study indicate that from the data on } \\
\text { the recapitulation of students' activeness in the discussion, CTL is able to } \\
\text { increase motivation shown by the activity of students in the discussion, it can } \\
\text { be seen from the number of students who are quite active from the first cycle } \\
\text { to the second cycle. Learning achievement of students from the first cycle to } \\
\text { the second cycle has increased, and classically with the application of } \\
\text { contextual learning methods / CTL (contextual teaching learning) fulfills an } \\
\text { increase in competency standards. Recapitulation of observational data about } \\
\text { contextual learning generally shows that students' responses increase, all in } \\
\text { the categories tend to agree and agree. }\end{array}$ \\
\hline
\end{tabular}

\section{ABSTRAK}

Kata kunci:

IPS Geografi,

Kontekstual,

Madrasah
Penelitian ini bertujuan untuk mengetahui; (1) Apakah implementasi metode pembelajaran berbasis kontekstual pada mata pelajaran IPS geografi kelas X dapat meningkatkan motivasi peserta didik? (2) Apakah implementasi metode pembelajaran berbasis kontekstual pada mata pelajaran IPS geografi kelas X dapat meningkatkan prestasi peserta didik? (3) Bagaimana tanggapan peserta didik kelas $X$ mengenai penerapan metode pembelajaran berbasis kontekstual pada mata pelajaran IPS geografi? Metode yang digunakan dalam penelitian ini adalah kuantitatif dengan pendekatan deskriptif analitis. Hasil penelitian ini menunjukkan bahwa dari data rekapitulasi keaktifan peserta didik dalam diskusi, metode pembelajaran CTL mampu meningkatkan motivasi yang ditunjukkan melalui keaktifan peserta didik dalam diskusi, terlihat dari jumlah peserta didik yang cukup aktif dari siklus pertama ke siklus kedua. Prestasi belajar peserta didik dari siklus pertama ke siklus kedua mengalami peningkatan, dan secara klasikal dengan diterapkannya metode pembelajaran kontektual/CTL (contextual teaching learning) memenuhi peningkatan standar kompetensi. Rekapitulasi data observasi tentang pembelajaran kontekstual secara umum menunjukkan bahwa respon peserta didik meningkat, semuanya dalam kategori cenderung setuju dan setuju. 


\section{PENDAHULUAN}

Dalam proses pembelajaran geografi di tingkat Madrasah Aliyah, sering terlihat banyak peserta didik yang kurang tertarik dan kurang bersemangat dalam mengikuti pelajaran tersebut. Motivasi peserta didik yang rendah ini disebabkan karena banyaknya istilah-istilah dalam pelajaran geografi yang menggunakan bahasa Yunani, disamping itu banyaknya materi yang diajarkan membuat peserta didik sulit untuk memahami tiap pembahasan yang disampaikan oleh guru. Dari hasil tes pada tahun sebelumnya, sebagai contoh dalam pembelajaran atmosfer dan hisrosfer kelas $\mathrm{X}$, penguasaan materi yang telah diajarkan masih rendah belum seperti yang diharapkan. Melalui pertanyaan-pertanyaan yang diberikan kepada peserta didik untuk menguji sejauh mana penguasaan mereka terhadap materi yang telah disampaikan, didapatkan bahwa peserta didik kurang memahami konsep materi yang diajarkan. Demikian pula dengan hasil belajar peserta didik yang belum sesuai dengan standar pencapaian Kriteria Ketuntasan Minimal (KKM).

Metode penyampaian materi pembelajaran yang digunakan oleh guru selama ini hanya menggunakan buku paket, diktat, memberikan catatan dan menggambarkan sketsa di white board. Guru mengajar dengan materi yang sama dari tahun ke tahun, catatan yang sama, banyak materi hafalan, gaya mengajar tidak berubah, standar dan terkesan sangat formal, sehingga jalannya proses penyampaian materi hanya berjalan searah. Hal ini dapat menimbulkan rasa bosan pada peserta didik karena peserta didik tidak banyak ikut aktif dalam proses belajar mengajar yang berlangsung. Guru perlu mengajar dengan berbagai variasi metode pengajaran, sehingga setiap peserta didik merasa disapa dan dikembangkan pengetahuannya sesuai dengan intelegensi mereka. Guru harus mendorong peserta didik untuk membangun dan mengembangkan pemikiran atau penalaran mereka sendiri. Sebagai mediator, guru membantu mengarahkan gagasan/ide/pemikiran peserta didik sesuai dengan konteks pelajaran, mendorong peserta didik memformulasikan dan merealisasikan gagasan mereka. Berkaitan dengan hal tersebut peneliti tertarik untuk menguji cobakan suatu model pembelajaran yang dapat meningkatkan motivasi dan minat peserta didik. Alternatif yang dipilih oleh peneliti yaitu implementasi pendekatan contextual teaching learning (CTL) dalam pembelajaran IPS geografi. Pemilihan 
metode CTL ini diharapkan mampu melibatkan peserta didik dalam keseluruhan proses pembelajaran dan seluruh aspek, yaitu kognitif, afektif maupun psikomotorik.

Pendekatan pembelajaran CTL adalah pembelajaran dengan membawa peserta didik ke dunia nyata sehingga motivasi belajar muncul, dunia pikiran peserta didik menjadi konkret, dan suasana menjadi kondusif, nyaman dan menyenangkan. Prinsip pembelajaran kontekstual menurut sumiati dan asra, (2007:16) adalah aktivitas peserta didik, peserta didik melakukan dan mengalami, tidak hanya menonton dan mencatat, dan pengembangan kemampuan sosialisasi. Peserta didik diberi pembelajaran untuk menangani permasalahan yang mereka hadapi ketika berhadapan dengan dunia nyata. Guru merencanakan situasi sedemikian rupa, sehingga para peserta didik bekerja menggunakan prosedur mengenali masalah, menjawab pertanyaan, menggunakan prosedur penelitian/investigasi, dan menyiapkan kerangka berpikir, hipotesis, dan penjelasan yang relevan dengan pengalaman pada dunia nyata. Tujuan dari penelitian ini adalah untuk mengetahui; (1) Apakah implementasi metode pembelajaran berbasis kontekstual pada mata pelajaran IPS geografi kelas X dapat meningkatkan motivasi peserta didik? (2) Apakah implementasi metode pembelajaran berbasis kontekstual pada mata pelajaran IPS geografi kelas $\mathrm{X}$ dapat meningkatkan prestasi peserta didik? (3) Bagaimana tanggapan peserta didik kelas $\mathrm{X}$ mengenai penerapan metode pembelajaran berbasis kontekstual pada mata pelajaran IPS geografi? Adapun lokasi penelitian dilakukan di Pesantren A di Kabupaten Sukoharjo.

\section{METODE}

Pendekatan yang digunakan dalam penelitian ini adalah kuantitatif dengan metode deskriptif analitis. Adapun yang dimaksud dengan tipe penelitian deskriptif ini adalah untuk membuat pencandraan (deskripsi) secara sistematis, faktual dan akurat mengenai fakta-fakta dan sifat-sifat populasi atau daerah tertentu. Penelitian deskriptif ini juga bertujuan untuk mencari informasi faktual yang mendetail serta mengidentifikasikan masalah-masalah atau untuk mendapatkan justifikasi keadaan dan praktek praktek yang sedang berlangsung (Suryabrata, 1988).

Menurut Sukardi (2009:14) penelitian deskriptif adalah penelitian yang berusaha menggambarkan kegiatan 
penelitian. Penelitian deskriptif ini juga disebut penelilian pra eksperimen karena dalam penelitian ini dilakukan eksplorasi, menggambarkan. dengan tnjuan unluk dapat menerangkan dan memprediksi terhadap sualu gejala yang berlaku atas dasar data yang diperoleh di lapangan. Penelilian deskriplif ini hanya berusaha menggambarkan secara jelas dan sekuensial terhadap pertanyaan penelitian yang lelah ditentukan sebelum para peneliti terjun ke lapangan dan mereka tidak menggunakan hipotesis sebagai petunjuk arah dalam penelitian.

Penelitian deskriptif adalah penelitian yang dimaksudkan untuk menyelidiki keadaan, kondisi atau hal lainlain yang sudah disebutkan, yang hasilnya dipaparkan dalam bentuk laporan penelitian. Dalam penelitian ini, peneliti tidak melakukan apa-apa terhadap objek atau wilayah yang diteliti, tidak menambah, mengubah, atau mengadakan manipulasi terhadap objek atau wilayah yang diteliti kemudian memaparkan apa yang terjadi.

Ada lima jenis penelitian deskriptif menurut Arikunto (2010 ; 3), (a) penelitian deskriptif murni atau survei, (b) penelitian korelasi, (c) penelitian komparasi, (d) penelitian penelusuran (tracer study), dan (e) penelitian evaluasi.

\section{PEMBAHASAN}

Belajar menurut Djamarah dan Zain (2002: 11), adalah proses perubahan perilaku berkat pengalaman dan latihan. Hal tersebut dapat difahami bahwa, tujuan kegiatan pembelajaran adalah perubahan tingkah laku, baik yang menyangkut pengetahuan, ketrampilan maupun sikap, bahkan meliputi segenap aspek organisme atau pribadi, sehingga dapat dikatakan bahwa hakekat belajar adalah perubahan. Adapun Hilgrad dan Bower (dalam Fudyartanto, 2002) mengatakan, belajar (to learn) memiliki arti: 1) to gain knowledge, comprehension, or mastery of trough experience or study; 2) to fix in the mind or memory; memorize; 3) to acquire trough experience; 4) to become in form of to find out. Definisi tersebut dapat difahami bahwa belajar bermakna memperoleh pengetahuan atau menguasai pengetahuan melalui pengalaman, mengingat, menguasai pengalaman, dan mendapatkan informasi atau menemukan. Dengan demikian, belajar memiliki arti dasar adanya aktivitas atau kegiatan dan penguasaan tentang sesuatu. Demikian pula Bell-Gredler (1986) dalam Udin S. Winataputra, dkk mengungkapkan bahwa belajar adalah proses yang dilakukan oleh manusia untuk mendapatkan aneka ragam competencies, 
skills, and attitudes. Kemampuan (competencies), keterampilan (skills), dan sikap (attitudes) tersebut diperoleh mulai dari masa bayi sampai masa tua melalui suatu rangkaian proses belajar sepanjang hayat yang dilakukan secara bertahap dan berkelanjutan. Keterlibatan individu dalam pendidikan baik informal, formal dan/atau pendidikan nonformal merupakan suatu rangkaian proses belajar.

Pernyataan tersebut juga diaminkan oleh Dimyati dan Mudjiono (2006:156), mereka mengatakan bahwa belajar adalah proses melibatkan manusia secara orang per-orang sebagai satu kesatuan organisme sehingga terjadi perubahan pada pengetahuan, keterampilan, dan sikap. Belajar merupakan salah satu faktor yang mempengaruhi dan berperan penting dalam pembentukan pribadi dan perilaku individu. Hilgard dan Bower (1966) dalam Jogiyanto (2006 ; 12) memberikan definsi pembelajaran sebagai suatu proses yang mana suatu kegiatan berasal atau berubah lewat reaksi dari suatu situasi yang dihadapi, dengan keadaan bahwa karakteristikkarakteristik dari perubahan aktivitas tersebut tidak dapat dijelaskan dengan dasar kecenderungan-kecenderungan reaksi asli, kematangan, atau perubahan- perubahan sementara dari organisme. Learning is the process by which an activity originates or is changed through reacting to an encountered situation, provided that the characteristics of the change in activity cannot be explained on the basis of native response tendencies, maturation, or temporary states of the organism. Pembelajaran terjadi ketika Anda berubah karena suatu kejadian dan perubahan yang terjadi bukan karena perubahan secara alami atau karena menjadi dewasa yang dapat terjadi dengan sendirinya atau karena perubahannya sementara saja, tetapi lebih karena reaksi dari situasi yang dihadapi.

Bloom menyatakan, bahwa belajar adalah perubahan perilaku yang terjadi sebagai hasil belajar meliputi perubahan dalam kawasan (domain) kognitif, afektif dan psikomotor, beserta tingkatan aspekaspeknya. Menurut Dimyati dan Mudjiono (2006:156), belajar adalah proses melibatkan manusia secara orang perorang sebagai satu kesatuan organisme sehingga terjadi perubahan pada pengetahuan, keterampilan, dan sikap. Oemar Hamalik (2007: 27) memberikan definisi yang sedikit berbeda tentang belajar sebagai sebuah modifikasi atau usaha untuk memperteguh kelakuan melalui pengalaman (learning is defined as 
the modification or strengthening of behavior through experiencing). Menurut pandangan ini belajar merupakan suatu proses, suatu kegiatan dan bukan suatu hasil atau tujuan. Belajar bukan hanya mengingat, akan tetapi lebih luas dari itu, yakni mengalami. Hasil belajar bukan suatu penguasaan hasil latihan melainkan pengubahan kelakuan. Menurut Djamarah dan Zain (2002: 11), juga mengatakan bahwa belajar adalah proses perubahan perilaku berkat pengalaman dan latihan. Artinya, tujuan kegiatan adalah perubahan tingkah laku, baik yang menyangkut pengetahuan, ketrampilan maupun sikap, bahkan meliputi segenap aspek organisme atau pribadi

Pernyataan tersebut didukung oleh Slameto (2003:3-4) yang mengemukakan ciri-ciri perubahan tingkah laku dalam pengertian belajar antara lain: perubahan terjadi secara sadar, bersifat kontinu dan fungsional, bersifat positif dan aktif, bukan bersifat sementara, bertujuan, mencangkup seluruh aspek tingkah laku. Perubahan yang terjadi sebagai akibat dari kegiatan belajar yang telah dilakukan oleh individu yang untuk mendapatkan hasil belajar dalam bentuk "perubahan" harus melalui proses tertentu yang dipengaruhi oleh faktor dari dalam diri individu dan di luar individu.
Sumiati dan Asra (2008:38), secara umum belajar dapat diartikan sebagai proses perubahan perilaku, akibat interaksi dengan lingkungannya. Tidak setiap perubahan perilaku dalam diri seseorang merupakan perubahan dalam arti belajar. Jadi hakekat belajar adalah perubahan, begitu pula sebagaimana yang dinyatakan Dimyati dan Mudjiono (2006:156), belajar adalah proses melibatkan manusia secara orang perorang sebagai satu kesatuan organisme sehingga terjadi perubahan pada pengetahuan, keterampilan, dan sikap. Hakekat pembelajaran adalah perubahan dalam tingkah laku si subyek dalam situasi tertentu berkat pengalamannya yang berulang-ulang, dan perubahan tingkah laku tersebut tidak dapat dijelaskan atas dasar kecenderungan respon bawaan, kematangan atau keadaan temporer dari subyek.

Demikan pula dalam pembelajaran IPS Geografi yang dilaksanakan di kelas X. Geografi merupakan ilmu yang mempelajari interaksi antara manusia dengan lingkungannya, geografi memiliki objek kajian dan ruang lingkup yang jelas. Objek studi geografi ada dua macam, yaitu objek studi material dan objek studi formal (menurut IGI/Ikatan Geografi Indonesia melalui seminar dan lokakarya 
nasional di Semarang tahun 1988). Objek material geografi merupakan sasaran atau hal-hal yang dikaji dalam studi geografi. Dan studi geografi adalah studi mengenai lapisan-lapisan bumi dan fenomena geosfer yang terdiri dari : (1) Litosfer yaitu lapisan kulit bumi terdiri atas tanah, sedimen, batu-batuan yang dikaji dalam geologi, geomorfologi, petrologi, dan lainlain. (2) Atmosfer yaitu lapisan udara, cuaca, dan iklim yang dikaji dalam meteorologi, klimatologi, dan lain-lain. (3) Biosfer yaitu lapisan bumi meliputi flora dan fauna yang dikaji dalam biogeografi, biologi, dan lain-lain. (4) Hidrosfer yaitu lapisan air meliputi perairan didarat maupun dilaut yang dikaji dalam hidrologi, oseanografi dan lain-lain. (5) Antroposfer yaitu lapisan manusia yang merupakan tema sentral/utama diantara lapisan-lapisan lain. sedangkan objek formal geografi merupakan cara atau metode dalam mengkaji dan menganalisis masalah-masalah objek material geografi.

Melihat materi-materi pelajaran IPS Geografi yang selalu terkait dengan alam dan lingkungan sekitar, maka pembelajaran yang dilakukan seyogyanya harus memberikan pengalaman langsung kepada peserta didik. Guru harus berupaya untuk membantu peserta didik memahami relevansi materi pembelajaran yang dipelajarinya adalah dengan melakukan suatu pendekatan yang memberikan kesempatan langsung kepada peserta didik untuk mengaplikasikan apa yang dipelajarinya di kelas. Pendekatan ini dikenal dengan pendekatan pembelajaran kontekstual (contextual teaching learning/CTL) pembelajaran kontekstual terfokus pada perkembangan ilmu, pemahaman, ketrampilan peserta didik, dan juga pemahaman kontekstual peserta didik tentang hubungan mata pelajaran yang dipelajarinya dengan dunia nyata. Pembelajaran akan bermakna jika guru lebih menekankan agar peserta didik mengerti relevansi apa yang mereka pelajari di sekolah dengan situasi kehidupan nyata dimana isi pelajaran akan digunakan.

Pembelajaran kontektual pada awalnya dikembangkan oleh John Dewey dari pengalaman pembelajaran tradisionalnya. Pada tahun 1918 Dewey merumuskan kurikulum dan metodologi pembelajaran yang berkaitan dengan pengalaman dan minat peserta didik. Peserta didik akan belajar baik jika yang dipelajarinya terkait dengan pengetahuan dan kegiatan yang telah diketahuinya dan terjadi di sekelilingnya. Pembelajaran kontektual adalah konsep belajar yang membantu guru mengaitkan antara materi 
pembelajaran yang diajarkan dengan situasi dunia nyata peserta didik dan mendorong peserta didik membuat hubungan antara pengetahuan yang dimilikinya dan penerapannya dalam kehidupan mereka sehari-hari. Pembelajaran kontekstual berbeda dengan pembelajaran tradisional, pembelajaran tradisional yang dimaksud tidak terbatas pada ceramah, diskusi, dan pertanyaan, serta latihan-latihan. Schell menyebutkan sepuluh perbedaan antara keduanya sebagaimana ditunjukkan pada tabel di bawah ini (Smith, 2010:25):

Tabel Perbedaan Pembelajaran Kontekstual dan Tradisional

\begin{tabular}{|c|c|}
\hline $\begin{array}{c}\text { Asumsi dan } \\
\text { Penerapan } \\
\text { Pembelajaran } \\
\text { Kontekstual (CTL) }\end{array}$ & $\begin{array}{l}\text { Asumsi dan } \\
\text { Penerapan } \\
\text { Pembelajaran } \\
\text { Tradisional }\end{array}$ \\
\hline $\begin{array}{c}\text { Peserta didik secara } \\
\text { aktif terlibat }\end{array}$ & $\begin{array}{c}\text { Peserta didik } \\
\text { adalah penerima } \\
\text { pasif }\end{array}$ \\
\hline $\begin{array}{c}\text { Peserta didik } \\
\text { memandang } \\
\text { pembelajaran } \\
\text { sebagai hal yang } \\
\text { relevan }\end{array}$ & $\begin{array}{c}\text { Peserta didik } \\
\text { menganggap } \\
\text { materi } \\
\text { pembelajaran } \\
\text { sebagai sesuatu } \\
\text { hal yang tidak } \\
\text { relevan untuk } \\
\text { diterapkan }\end{array}$ \\
\hline $\begin{array}{c}\text { Peserta didik } \\
\text { belajar dari satu } \\
\text { sama lain melalui } \\
\text { kerja sama, wacana, } \\
\text { kerja tim, dan } \\
\text { refleksi diri }\end{array}$ & $\begin{array}{c}\text { Peserta didik } \\
\text { bekerja dalam } \\
\text { isolasi. Ulasan } \\
\text { dan/atau diskusi } \\
\text { ditiadakan }\end{array}$ \\
\hline
\end{tabular}

\begin{tabular}{|c|c|}
\hline $\begin{array}{c}\text { Belajar } \\
\text { berhubungan } \\
\text { dengan "dunia } \\
\text { nyata" dan/atau } \\
\text { masalah simulasi } \\
\text { dan masalah yang } \\
\text { berarti }\end{array}$ & $\begin{array}{c}\text { Belajar itu abstrak } \\
\text { dan teoritis }\end{array}$ \\
\hline $\begin{array}{c}\text { Peserta didik } \\
\text { didorong untuk } \\
\text { bertanggung jawab } \\
\text { atas pemantauan } \\
\text { dan pengembangan } \\
\text { pembelajaran } \\
\text { mereka sendiri }\end{array}$ & $\begin{array}{c}\text { Guru dianggap } \\
\text { sebagai satu- } \\
\text { satunya wasit } \\
\text { dalam } \\
\text { pembelajaran } \\
\text { peserta didik }\end{array}$ \\
\hline
\end{tabular}
Menghargai konteks Sedikit atau tidak kehidupan beragam ada pertimbangan peserta didik dan diberikan kepada pengalaman pengalaman dan sebelumnya sangat latar belakang penting untuk peserta didik dipelajari

\begin{tabular}{cc}
\hline Peserta didik & Peserta didik tidak \\
didorong untuk & didorong untuk \\
menjadi peserta & terlibat dalam \\
aktif dalam & pengembangan \\
pengembangan & masyarakat \\
masyarakat &
\end{tabular}

Pembelajaran peserta didik dinilai dalam berbagai cara

Pembelajaran
peserta didik dinilai
dalam berbagai cara

Pembelajaran dinilai dalam format tunggal dan terstandardisasi

\begin{tabular}{cc}
\hline $\begin{array}{c}\text { Perspektif dan } \\
\text { pendapat peserta } \\
\text { didik dihargai dan } \\
\text { dihormati }\end{array}$ & $\begin{array}{c}\text { Perspektif peserta } \\
\text { didik tidak } \\
\text { diminta atau } \\
\text { undervalued }\end{array}$ \\
\hline $\begin{array}{c}\text { Guru bertindak } \\
\text { sebagai fasilitator } \\
\text { pembelajaran } \\
\text { peserta didik }\end{array}$ & $\begin{array}{c}\text { Kontrol guru dan } \\
\text { mendikte } \\
\text { merupakan aspek } \\
\text { instruksional }\end{array}$ \\
\hline \multicolumn{2}{c}{ Sumber: Smith, 2010 }
\end{tabular}


Pembelajaran kontekstual (contextual teaching and learning) sebagaimana dikemukakan oleh Berns dan Erikson dikenal sebagai pendekatan pembelajaran yang dapat mengisi kesenjangan antara teori ilmu pengetahuan dan konteks kehidupan. Dalam pembelajaran kontekstual peserta didik dibimbing untuk belajar ilmu pengetahuan dalam konteks kehidupan dan memotivasi peserta didik untuk menemukan relevansi pembelajaran mereka dengan dunia nyata. Proses pembelajaran kontekstual ditekankan pada hubungan yang bermakna, kontruktivisme, inkuiri, berpikir kritis dan kreatif, learning community, dan penilaian autentik (Johnson, 2002; Glynn \& Winter, 2004; Klassen, 2006) dalam Adlim, Samingan, dan Hasibuan (2014:112). Pembelajaran kontekstual (contextual teaching and learning) adalah sistem yang komprehensif, terdiri dari beberapa bagian yang terkoneksi satu sama lain. jika bagian-bagian tersebut terkait satu sama lain, mereka akan memberikan efek yang menghasilkan efek yang melebihi hasil yang diberikan dari bagian-bagiannya secara terpisah. Johnson menyebutkan bahwa Pembelajaran kontekstual (contextual teaching and learning) memiliki delapan komponen yaitu (Rahman, Thalib, dan Mahmud, 2017:56):

1. Menciptakan hubungan yang bermakna

2. Melakukan pekerjaan yang bermakna

3. Melakukan pembelajaran mandiri

4. Bekerja sama

5. Melakukan pemikiran kritis dan kreatif

6. Membantu individu untuk tumbuh dan berkembang

7. Mencapai standar yang tinggi

8. Menggunakan penilaian autentik

Dengan demikian dapat difahami bahwa pembelajaran kontekstual adalah pembelajaran yang mengutamakan pada pengetahuan dan pengalaman di dunia nyata (real world learning), berpikir tingkat tinggi, berpusat pada peserta didik, peserta didik aktif, kritis, kreatif, memecahkan masalah, peserta didik belajar menyenangkan, mengasyikkan, tidak membosankan, dan menggunakan berbagai sumber belajar. Menurut Johnson pembelajaran kontekstual (contextual teaching and learning) memiliki tiga prinsip yaitu; (1) Prinsip Interrelasi, (2) Prinsip Diferensiasi, dan (3) Prinsip Regulasi Diri (Rahman, Thalib, dan Mahmud, 2017:56). Adapun Philip Baron (2016:95-96) dalam artikelnya yang berjudul $A$ Cybernetic Approach to Contextual Teaching and Learning 
mengemukakan enam prinsip dalam pembelajaran kontekstual, antara lain:

1. Ciptakan ruang bagi peserta didik untuk mendapatkan pengalaman di dunianya dengan mengundang peserta didik lain untuk berpartisipasi aktif dalam penciptaan pengetahuan.

2. Mengadopsi heterarki (struktur otoritas hizontal) disamping hirarki (struktur otoritas vertikal) dengan mengijinkan peserta didik menjadi kokreator di kelas.

3. Mengundang para peserta didik untuk membahas tujuan, sasaran, dan gaya belajar yang mereka inginkan.

4. Tetapkan konteks dan pengalaman peserta didik dari sudut pandang mereka sebagai lintasan untuk mengetahui hasil pembelajaran di kelas dibawah arahan guru dan peserta didik secara bersama-sama.

5. Gabungan informasi baru tersebut ke dalam kurikulum, membuat silabus yang secara khusus relevan bagi para peserta didik yang hadir di kelas, karena berasal dari keterlibatan peserta didik baik secara implisit maupun eksplisit.

6. Tunjukkan tanggung jawab yang muncul dari pengetahuan yang diciptakan secara komunal ini, lakukan pengukuran kesesuaiannya dengan tujuan jangka panjang pendidikan yaitu kemitraan dengan kebutuhan dunia industri dan organisasi profesional/badan terakreditasi lainnya.

Pembelajaran kontektual memiliki beberapa manfaat diantaranya sebagaimana yang dilansir dalam website USA Today's yaitu; (1) peserta didik lebih responsif ketika menggunakan pengetahuan dan keterampilan mereka dalam situasi dunia nyata; (2) peserta didik lebih cenderung terlibat dalam pembelajaran mereka sendiri jika itu diterapkan secara langsung ke hidup mereka sebagai anggota keluarga, warga negara, dan pekerja masa kini/masa depan; dan (3) orang tua, peserta didik, dan anggota masyarakat dapat menggunakan dan berhubungan dengan ide-ide ini. Lebih lanjut para peneliti dari Fakultas Pendidikan Universitas Georgia juga menemukan manfaat penggunaan dan pengajaran dan pembelajaran kontekstual di kelas (Smith, 2010:25-26).

Para peneliti dari Universitas Georgia meluangkan waktu selama 5 tahun untuk mempelajari bagaimana para guru membuat pengajaran dan pembelajaran kontekstual menjadi kenyataan. Dua manfaat utama yang diberikan oleh guru pemula dan guru pendidikan teknis dan 
guru akademik yang berpartisipasi dalam penelitian Fakultas Pendidikan Universitas Georgia yang ditemukan dalam menggunakan strategi Pengajaran dan Pembelajaran Kontekstual. Pertama, peserta didik melaporkan bahwa mereka belajar lebih banyak di kelas strategi Pengajaran dan Pembelajaran Kontekstual daripada di kelas dengan metode tradisional lainnya pada subjek atau materi yang sama. Dasar pemikiran yang melandasi keberhasilan peserta didik adalah bahwa mereka mempelajari materi dalam konteks konkret, sehingga memperkuat ingatan. Kedua, peserta didik lebih termotivasi dalam kelas Pengajaran dan Pembelajaran Kontekstual karena mereka menanggapi dengan baik strategi terkait. Ketika peserta didik melihat relevansi dunia nyata dari apa yang mereka pelajari, mereka menjadi lebih tertarik dan termotivasi; ini terutama berlaku bagi peserta didik yang menganggap sekolah membosankan (Smith, 2010:25-26).

Pemilihan model pembelajaran kontekstual (contextual teaching learning/CTL) dikarenakan pembelajaran kontekstual terfokus pada perkembangan ilmu, pemahaman, ketrampilan peserta didik, dan juga pemahaman kontekstual peserta didik tentang hubungan mata pelajaran yang dipelajarinya dengan dunia nyata. Model pembelajaran kontekstual dimaksudkan agar peserta didik memahami relevansi materi pembelajaran yang dipelajarinya dengan melakukan suatu pendekatan yang memberikan kesempatan langsung kepada peserta didik untuk mengaplikasikan apa yang dipelajarinya di kelas baik secara modeling, constructivism, inquiry dan learning community. Sebelum melaksanakan penelitian, tahap awal yang dilakukan oleh peneliti adalah menyusun rencana pembelajaran dan teknik pembelajaran yang lebih efektif sesuai dengan tingkat kemampuan peserta didik serta menyiapkan media dan alat peraga yang dibutuhkan. Penelitian ini memilih materi pembelajaran menganalisis atmosfer dan hidrosfer serta dampaknya terhadap kehidupan di muka bumi dalam mata pelajaran IPS geografi untuk dimodifikasi sesuai konsep pembelajaran kontektual. Materi menganalisis atmosfer dan hidrosfer serta dampaknya terhadap kehidupan di muka bumi sangat berkaitan dengan dunia nyata serta membahas fenomena-fenomena yang terjadi dalam kehdupan sehari-hari. Penelitian ini terdiri dari dua siklus yang masing-masing siklusnya terdiri dari tahapan; persiapan, 
tindakan, observasi, serta analisis dan refleksi.

\section{Siklus Pertama}

Tahap perencanaan dilakukan dengan langkah-langkah;

(1) Persiapan

administrasi pembelajaran:

Menyiapkan perangkat pembelajaran berupa Rencana Pelaksanaan Pembelajaran (RPP) yang telah disusun pada awal semester dan menyusun pedoman observasi. (b) Menyiapkan materi menganalisis Atmosfer dan Hidrosfer serta dampaknya terhadap kehidupan di muka bumi dengan merancang beberapa project sederhana yang berbasis pada modeling, constructivism, inquiry dan learning community dan menyiapkan media sebagai sumber belajar peserta didik yang berupa bahan project sederhana, LCD, white screen untuk presentasi. (c) Menyusun soal tes untuk mengetahui sejauh mana kemampuan keterampilan peserta didik yang dimiliki. (2) Persiapan pelaksanaan pembelajaran : Menyiapkan daftar pembagian kelompok dan menjelaskan peran masing-masing kelompok dalam project (b) Menyiapkan lembar observasi guru, (c) Menyiapkan lembar observasi peserta didik yang terdiri dari observasi respon peserta didik tentang problem pembelajaran kontekstual, observasi keaktifan peserta didik dalam kelompok, angket proses dalam kelompok, observasi keaktifan dalam diskusi (d) menyiapkan daftar nilai hasil evaluasi.

Tahap tindakan adalah tahap pelaksanaan pembelajaran kontekstual pada materi menganalisis Atmosfer dan Hidrosfer serta dampaknya terhadap kehidupan di muka bumi dengan berpedoman pada RPP yang telah disusun. Selanjutnya dalam pelaksanaan pembelajaran tetap mengacu pada 7 (tujuh) ciri pembelajaran kontekstual yaitu modeling, questioning, learning community, inquiry, constructivism, reflection, dan authentic assessment. Langkah awal adalah dengan membentuk masyarakat belajar (learning community) peserta didik dibagi kedalam 5 (lima) kelompok yang masing-masing memilih topik sesuai ketertarikan mereka pada materi yang akan mereka pelajari. Anggota kelompok dibuat heterogen berdasarkan kemampuan mereka. Pada tahap selanjutnya masing-masing kelompok diberikan project sederhana berdasarkan materi masing-masing kelompok.

Kelompok pertama membahas mengenai lapisan dan unsur-unsur gas, metode yang dipakai adalah 
constructivism, menyusun konsep sendiri dengan mencari dan mengacu pada konsep yang ada dari berbagai sumber (buku perpustakaan, internet dan CD pembelajaran), kelompok kedua membahas mengenai temperatur, metode yang dipakai adalah inquiry yaitu dengan menemukan penyebab terjadinya perbedaan temperatur di permukaan bumi melalui pengamatan dan pengukuran langsung di lapangan, kelompok ketiga membahas mengenai kelembaban metode yang dipakai adalah modelling yaitu dengan meletakkan garam dapur diatas kertas peserta didik mengamati, menyusun hippotesis dan memberikan kesimpulan mengenai perbedaan perubahan garam dapur yang diletakkan di dalam dan di luar ruangan, kelompok keempat membahas mengenai tekanan udara dan angin metode yang dipakai adalah modelling melalui balón yang berisi udara peserta didik mengidentifikasikan perbedaan tekanan udara dan penyebab terjadinya angin, kelompok kelima membahas mengenai macam-macam hujan dan awan metode yang dipakai adalah inquiry dan discovery peserta didik mencari dan menemukan secara langsung dengan melihat di luar ruangan macam-macam awan yang ada dan mengidentifikasikan proses terjadinya hujan.

Pada pertemuan kedua, peserta didik dilatih membuat makalah untuk dipresentasikan berdasarkan informasiinformasi yang diperoleh dari berbagai sumber. disini peran guru untuk membimbing masing-masing peserta didik dalam kelompok berdiskusi menyusun bahan informasi menjadi makalah dan membuat presentasi untuk dipresentasikan. Kemudian peserta didik dilatih untuk mempresentasikan hasil makalah yang disusun tiap-tiap kelompok sedang kelompok yang lain untuk menanggapi dari makalah yang dipresentasikan pada saat diskusi. Peserta didik dalam kelompok diberi tugas yang berbeda, ada yang bertugas mempresentasikan, menjadi moderator, maupun menjadi sekretaris maupun anggota untuk membantu sekretaris dan membantu yang lain dalam menjawab pertanyaan maupun sanggahan. Data keaktifan peserta didik dalamkelompok ditunjukkan dalam tabel di bawah ini:

Tabel Keaktifan Peserta Didik dalam Kelompok Siklus 1

\begin{tabular}{clccc}
\hline \multirow{2}{*}{ NO } & \multirow{2}{*}{ KRITERIA } & \multirow{2}{*}{ POIN } & \multicolumn{2}{c}{ Siklus 1 } \\
\cline { 3 - 5 } & & & Jml & $\mathbf{\%}$ \\
\hline 1 & Aktif & $21-30$ & 10 & 33,4 \\
\hline 2 & Cukup aktif & $11-20$ & 13 & 43,4 \\
\hline 3 & Kurang aktif & $1-10$ & 7 & 23,2 \\
\hline & Jumlah & & 30 & 100 \\
\hline
\end{tabular}


Dari data tabel di atas dapat di analisa bahwa jumlah peserta didik yang aktif dalam penyusunan materi sebanyak 10 peserta didik (33,4 \%), cukup aktif sebanyak 13 peserta didik (43,4\%), dan peserta didik yang kurang aktif sebanyak 7 peserta didik (23,2 \%). Adapun data rekapitulasi keaktifan peserta didik dalam diskusi kelas terlihat dari jumlah peserta didik yang cukup aktif dari siklus pertama sebanyak 13 peserta didik (43,2\%), aktif dan sangat aktif 5 peserta didik (16,8\%), kurang aktif sebanyak 8 peserta didik $(26,6 \%)$ dan tidak aktif sebanyak 4 peserta didik $(3,4 \%)$.

Tabel Keaktifan Peserta Didik dalam Diskusi Siklus 1

\begin{tabular}{clccc}
\hline \multirow{2}{*}{ NO } & \multirow{2}{*}{ KRITERIA } & \multirow{2}{*}{ POIN } & \multicolumn{2}{c}{ Siklus 1 } \\
\cline { 3 - 5 } & & Jml & \% \\
\hline 1 & Sangat aktif & 4 & 4 & 13,4 \\
\hline 2 & Aktif & 3 & 1 & 3,4 \\
\hline 3 & Cukup aktif & 2 & 13 & 43,2 \\
\hline 4 & Kurang aktif & 1 & 8 & 26,6 \\
\hline 5 & Tidak aktif & 0 & 4 & 13,4 \\
\hline & Jumlah & & 30 & 100 \\
\hline
\end{tabular}

Pada pertemuan ketiga dari siklus satu ini peserta didik diberi evaluasi secara individu, untuk materi menganalisis Atmosfer dan Hidrosfer serta dampaknya terhadap kehidupan di muka bumi mata pelajaran IPS geografi. Hasil evaluasi menunjukkan bahwa prestasi belajar peserta didik dalam menganalisis Atmosfer dan Hidrosfer serta dampaknya terhadap kehidupan di muka bumi diperoleh 23 (76,80\%) dari 30 peserta didik sudah memenuhi KKM (Kriteria Ketuntasan Minimum $=75,00$ ). Sedangkan dari 23 peserta didik yang tuntas tersebut, 16 peserta didik $(53,40$ \%) mendapatkan nilai melebihi KKM. adapun peserta didik yang perlu remidi karena belum memenuhi KKM masih terdapat 7 orang $(23,20 \%)$.

Pada akhir proses siklus pertama ini peserta didik diberi lembar observasi untuk mengetahui respon peserta didik terhadap pembelajaran dengan menggunakan metode CTL Dari hasil observasi tentang respon peserta didik pada pembelajarn CTL diperoeh rata-rata tertinggi 30,89 pada pilihan jawaban ke-3 yang menunjukkan bahwa peserta didik masih ragu-ragu dan cenderung setuju tentang penggunaan metode kontekstual dalam pembelajaran menganalisis atmosfer dan menganalisis hidrosfer serta dampaknya terhadap kehidupan di muka bumi.

\section{Siklus Kedua}

Langkah-langkah tahap perencanaan pada siklus kedua sama dengan langkahlangkah tahap perencanaan pada siklus pertama, adapun tahap tindakannya berupa langkah awal adalah dengan membentuk masyarakat belajar (learning 
community) peserta didik dibagi kedalam 5 (lima) kelompok yang masing-masing memilih topik sesuai ketertarikan mereka pada materi yang akan mereka pelajari. Anggota kelompok dibuat heterogen berdasarkan kemampuan mereka. Pada tahap selanjutnya masing-masing kelompok diberikan tugas berdasarkan materi masing-masing kelompok. Pada siklus kedua ini para peserta didik diajak langsung mengenal unsur-unsur siklus hidrosfer melalui sebuah studi lapangan. Pada pertemuan pertama peneliti menyampaikan tujuan dengan lebih deskriptif, melakukan apersepsi dengan menghubungkan pelajaran yang sekarang dengan pelajaran yang lalu serta memberikan contoh pada dunia nyata, membagi peserta didik kedalam kelompok-kelompok yang heterogen serta memberikan arahan mengenai tugas masing-masing kelompok. Para peserta didik diberikan waktu mencari dari berbagai sumber mengenai tugas yang akan mereka kerjakan sebelum diajak langsung mengamati fenomena berbagai jenis perairan laut, danau,/bendungan, sungai, air kapiler, rawa dan air artesis melalui studi lapangan.

Pada pertemuan kedua, peserta didik dilatih membuat makalah untuk dipresentasikan. Peran guru dalam pembuatan makalah adalah dengan memberikan bimbingan pada masing masing peserta didik dalam kelompok. Guru menjadi bagian dalam diskusi untuk menyusun bahan informasi menjadi makalah dan membuat presentasi untuk dipresentasikan. Kemudian peserta didik dilatih untuk mempresentasikan hasil makalah yang disusun tiap-tiap kelompok, sedangkan kelompok yang lain dipersilahkan menanggapi materi yang dipresentasikan pada saat diskusi. Peserta didik diberi tugas yang berbeda dalam kelompok, ada yang bertugas mempresentasikan, menjadi moderator, menjadi sekretaris maupun anggota, yang berfungsi untuk membantu sekretaris dan anggota lain dalam menjawab pertanyaan maupun sanggahan. Berkaitan dengan keaktifan peserta didik pada siklus ke-2 ini, data yang didapatkan dari observasi di lapangan ditunjukkan dalam tabel berikut di bawah ini:

Tabel Keaktifan Peserta Didik dalam Kelompok Siklus 2

\begin{tabular}{|c|c|c|c|c|}
\hline \multirow{2}{*}{ NO } & \multirow{2}{*}{ KRITERIA } & \multirow{2}{*}{ POIN } & \multicolumn{2}{|c|}{ Siklus 2} \\
\hline & & & Jml & $\%$ \\
\hline 1 & Aktif & $21-30$ & 13 & 43,4 \\
\hline 2 & Cukup aktif & $11-20$ & 14 & 46,6 \\
\hline 3 & Kurang aktif & $1-10$ & 3 & 10,0 \\
\hline & Jumlah & & 30 & 100 \\
\hline
\end{tabular}

Dari data tabel di atas dapat di analisa bahwa jumlah peserta didik yang cukup 
aktif yaitu dari 13 peserta didik (43,4\%) pada siklus pertama, menjadi 14 peserta didik (46,6\%) pada siklus kedua. Peserta didik yang aktif dalam penyusunan materi mengalarni peningkatan dari 10 peserta didik $(33,4 \%)$ pada siklus pertama, menjadi 13 peserta didik $(43,4 \%)$ pada siklus kedua. Begitu pun dengan peserta didik yang kurang aktif telah mengalami penurunan yaitu dari 7 peserta didik $(23,2$ $\%)$ pada siklus pertama, menjadi 3 peserta didik (10,0\%) pada siklus kedua.

Tabel Keaktifan Peserta Didik dalam Diskusi Siklus 2

\begin{tabular}{clccc}
\hline \multirow{2}{*}{ NO } & \multirow{2}{*}{ KRITERIA } & \multirow{2}{*}{ POIN } & \multicolumn{2}{c}{ Siklus 2 } \\
\cline { 3 - 5 } & & Jml & $\mathbf{\%}$ \\
\hline 1 & Sangat aktif & 4 & 7 & 23,4 \\
\hline 2 & Aktif & 3 & 4 & 13,4 \\
\hline 3 & Cukup aktif & 2 & 14 & 46,6 \\
\hline 4 & Kurang aktif & 1 & 5 & 16,6 \\
\hline 5 & Tidak aktif & 0 & 0 & 0,0 \\
\hline \multicolumn{2}{r}{ Jumlah } & & 30 & 100 \\
\hline
\end{tabular}

Dari data rekapitulasi keaktifan peserta didik dalam diskusi siklus kedua, dapat disimpulkan bahwa metode pembelajaran CTL mampu meningkatkan keaktifan diskusi. Peserta didik yang cukup aktif dan aktif pada siklus pertama, sebanyak 13 peserta didik (43,2 \%) meningkat menjadi 14 peserta didik (46,6\%) pada sikus kedua. Peserta didik yang aktif dan sangat aktif mengalami peningkatan dari 5 (16,8\%) pada siklus pertama, menjadi 11 peserta didik $(36,8$
\%) pada siklus kedua. Sedangkan peserta didik yang kurang aktif hanya sebanyak 5 peserta didik $(16,6 \%)$ dan tidak ada peserta didik yang tidak mengambil bagian dalam diskusi pada siklus yang kedua ini.

Pada pertemuan ketiga dari siklus kedua ini peserta didik diberi evaluasi secara individu, untuk materi menganalisis Atmosfer dan Hidrosfer serta dampaknya terhadap kehidupan di muka bumi mata pelajaran IPS geografi. Pada akhir proses siklus kedua, peserta didik diberi lembar observasi untuk diisi. Hasil prestasi belajar peserta didik dalam menganalisis Atmosfer dan Hidrosfer serta dampaknya terhadap kehidupan di muka bumi pada siklus kedua, diperoleh hasil bahwa 27 peserta didik (90,00\%) dari 30 peserta didik sudah memenuhi KKM (Kriteria Ketuntasan Minimum = 75,00). Adapun dari 27 peserta didik yang tuntas tersebut, 15 orang atau sekitar 50,00 \%-nya sudah melebihi KKM. Demikian juga untuk prosentase peserta didik yang masih memerlukan remidi mengalami penurunan dari 7 orang $(23,20$ \%) pada siklus pertama, menjadi 3 orang (10,00\%) pada siklus kedua.

Pada akhir proses siklus kedua ini peserta didik diberi lembar observasi untuk mengetahui respon peserta didik 
terhadap pembelajaran dengan menggunakan metode CTL Dari hasil observasi tentang respon peserta didik pada pembelajarn CTL diperoleh rata-rata 31,33 dan 26,00 pada pilihan jawaban ke4 dn ke-5 yang menunjukkan bahwa peserta didik cenderung setuju dan setuju tentang penggunaan metode kontekstual dalam pembelajaran menganalisis atmosfer dan menganalisis hidrosfer serta dampaknya terhadap kehidupan di muka bumi.

Pembelajaran kontekstual adalah pembelajaran yang dimulai dengan sajian atau tanya jawab lisan (ramah, terbuka, negosiasi) yang terkait dengan dunia nyata kehidupan peserta didik (daily life modeling), sehingga akan terasa manfaat dari materi yang akan disajikan, motivasi belajar muncul, alam pikir peserta didik menjadi konkret, dan suasana menjadi kondusif, nyaman dan menyenangkan. Prinsip pembelajaran kontekstual adalah aktivitas peserta didik, peserta didik melakukan dan mengalami, tidak hanya menonton dan mencatat, serta pengembangan kemampuan sosialisasi. Ada tujuh indikator pembelajarn kontekstual sehingga bisa dibedakan dengan model lainnya, yaitu modeling (pemusatan perhatian, motivasi, penyampaian kompetensi-tujuan, pengarahan-petunjuk, rambu-rambu, contoh), questioning (eksplorasi, membimbing, menuntun, mengarahkan, mengembangkan, evaluasi, generalisasi), learning community (seluruh peserta didik partisipatif dalam belajar kelompok atau individual, minds-on, hands-on, mencoba, mengerjakan), inquiry (identifikasi, investigasi, hipotesis, konjektur, generalisasi, menemukan), constructivism (membangun pemahaman sendiri, mengkonstruksi konsep-aturan, analisissintesis), reflection (reviu, rangkuman, tindak lanjut), authentic assessment (penilaian selama proses dan sesudah pembelajaran, penilaian terhadap setiap aktvitas-usaha peserta didik, penilaian portofolio, penilaian seobjektif-objektifnya dari berbagai aspek dengan berbagai cara).

\section{SIMPULAN}

Hasil analisis dan evaluasi pada kompetensi dasar menganalisis Atmosfer dan Hidrosfer serta dampaknya terhadap kehidupan di muka bumi mata pelajaran IPS geografi, dapat disimpulkan bahwa: (1) Motifasi peserta didik meningkat terlihat dari aktifitas peserta didik dalam berdiskusi. Dapat di analisis bahwa jumlah peserta didik yang cukup aktif yaitu dari 13 peserta didik $(43,4 \%)$ pada siklus pertama, menjadi 14 peserta didik 
$(46,6 \%)$ pada siklus kedua dan aktif dalam penyusunan materi mengalarni peningkatan yaitu dari 10 peserta didik (33,4 \%) pada siklus pertama, menjadi 13 peserta didik $(43,4 \%)$ pada siklus kedua, adapun peserta didik kurang aktif mengalarni penurunan yaitu dari 7 peserta didik (23,2 \%) pada siklus pertama, menjadi 3 peserta didik $(10,0 \%)$ pada siklus kedua. Dari data rekapitulasi keaktifan peserta didik dalam diskusi dapat disimpulkan bahwa metode pembelajaran CTL mampu meningkatkan motivasi yang ditunjukkan melalui keaktifan peserta didik dalam diskusi, terlihat dari jumlah peserta didik yang cukup aktif dari siklus 1 sebanyak 13 peserta didik (43,2 \%) pada siklus pertama, menjadi 14 peserta didik (46,6\%) pada siklus kedua, dan sangat aktif dari $4(13,4 \%)$ menjadi 7 peserta didik (23,4\%). (2) Hasil prestasi belajar peserta didik dari siklus pertama ke siklus kedua mengalami peningkatan dan secara klasikal dengan diterapkannya metode pembelajaran kontektual/CTL (contextual teaching learning) memenuhi peningkatan standar kompetensi dari siklus pertama sebesar 76,60 \% menjadi sebesar 90,00 \% pada siklus kedua, atau meningkat sebesar 13,4 \%. (3) Dari paparan data rekapitulasi observasi peserta didik tentang pembelajaran kontekstual secara umum respon peserta didik meningkat, semuanya dalam kategori cenderung setuju dan setuju. Dari hasil observasi tentang respon peserta didik pada pembelajaran CTL peserta didik senang dan menyukai tentang penggunaan metode kontekstual pada materi menganalisis atmosfer dan menganalisis hidrosfer mata pelajaran IPS geografi, hal ini terlihat dari hasil angket respon peserta didik pada pembelajaran kontekstual yang bergeser dari ragu-ragu kearah cenderung setuju dan setuju.

\section{DAFTAR PUSTAKA}

Arikunto, Suharsimi. 2010. Prosedur Penelitian; Suatu Pendekatan Praktik. Jakarta: Rineka Cipta.

Adlim, M, Samingan, dan Hasibuan, Rossy Anggelia. 2014. Integrating Entrepreneurial Practice in Contextual Learning of Biotechnology for Senior High School Students. Journal of Turkish Science Education, Vol. 11, 2, June.

Baron, Philip. 2016. A Cybernetic Approach to Contextual Teaching and Learning. Constructivist Foundations, Vol. 12, No. 1.

Dimyati dan Mudjiono. 2006. Belajar dan Pembelajaran. Jakarta: PT Rineka Cipta.

Djamarah, Syaiful Bahri dan Zain, Aswan. 2002. Strategi Belajar Mengajar. Jakarta: Rineka Cipta. 
Fudyartanto, Ki RBS. 2002. Psikologi Pendidikan dengan Pendekatan Baru. Jogjakarta: Global Pustaka Ilmu.

Hamalik, Omar. 2007. Proses Belajar Mengajar. Jakarta: Bumi Aksara.

http://www.geografi.web.id. 2009. Ruang Lingkup Geografi.

Jogiyanto. 2006. Filosofi, Pendekatan, dan Penerapan Pembelajaran Metode Kasus. Yogyakarta: Andi Offset

Rahman, Hardiyanto, Thalib, Syamsul Bachri, dan Mahmud, Alimuddin. 2017. Integrated Character Education in Social Sciences with Contextual Teaching and Learning Approach. The New Educational Review, 48, 2, 04.

Slameto. 2003. Belajar dan Faktorfaktor yang Mempengaruhinya. Jakarta: Rineka Cipta.

Smith, Bettye P. 2010. Instructional Strategies in Family and Consumer Sciences: Implementing the Contextual Teaching and Learning Pedagogical Model. Journal of Family \& Consumer Sciences Education, 28, No. 1.

Sumiati dan Asra. 2008. Metode Pembelajaran. Bandung: CV Wacana Prima.

Sukardi. 2009. Metodologi Penelitian Pendidikan, Kompetensi dan Praktiknya. Jakarta: Bumi Aksara.

Suryabrata, Sumadi. 1988. Metodologi Penelitian, CV.Rajawali, Jakarta.

Udin S. Winataputra, Rudi Susilana, Siti Julaeha, \& Wina Sanjaya. 2007. Teori Belajar dan Pembelajaran. Jakarta: Universitas Terbuka. 